\title{
Molecular cloning of a member of a new class of low-molecular-weight GTP-binding proteins
}

\author{
Bruce H. Morimoto, Chan-Chou Chuang, and Daniel E. Koshland Jr. ${ }^{1}$ \\ Department of Molecular and Cell Biology, Division of Biochemistry and Molecular Biology, University of California, \\ Berkeley, California 94720 USA
}

\begin{abstract}
We report the cloning of a low-molecular-weight GTP-binding protein that appears to be the first member of a new class of $G$ proteins. This $G$ protein was cloned from the HT4 neural cell line and has the closest homology to the rab, sec4, and ypt1 members of the low-molecular-weight (LMW) G-protein family. The amino acid sequence identity is only $30 \%$ with these other LMW G proteins, but in the four conserved GTP-binding domains, amino acid identity increases to $50-100 \%$. A unique feature that distinguishes this $G$ protein from other LMW G proteins is its carboxy-terminal amino acid sequence-Cys-Cys-Pro. In keeping with the current nomenclature for other members of the ras superfamily, we will designate this new class as rah (ras-related homolog). On the basis of sequence homology, rah may function in vesicular trafficking and possibly in neurotransmitter secretion.
\end{abstract}

[Key Words: ras; rab; ypt1; sec4; small G protein]

Received October 7, 1991; revised version accepted October 30, 1991.

Low-molecular-weight (LMW) GTP-binding proteins are a rapidly growing family of proteins in which the ras oncogene is the prototype. The members of this diverse collection of proteins function in a number of cellular processes including the regulation of growth metabolism, protein sorting, and neurotransmitter secretion (see Bourne et al. 1990, 1991; Hall 1990).

These small G proteins consist of a single polypeptide chain of 21-30 kD and are able to bind and hydrolyze GTP. By analogy with the larger heterotrimeric G proteins, the binding of GTP may turn on or activate the LMW G proteins to send a signal to an acceptor molecule (Bourne 1988). The intrinsic GTPase activity would then be responsible for turning the signal off. The precise mechanism by which these small $G$ proteins integrate into cellular metabolism remains elusive.

Of the ras-related small G proteins, a subset of them appear to be critical in the regulation of membrane vesicle transport. The best genetic evidence comes from two yeast mutants, sec4 and ypt1. In Saccharomyces cerevisiae, mutations in sec4 result in the accumulation of vesicles at the plasma membrane, suggesting that the Sec4 gene product is critical for the fusion of vesicles with the plasma membrane (Walworth et al. 1989). Disruption of ypt1 is lethal; however, the use of temperature-sensitive mutations has shown that the Yptl gene product is involved in an early stage of vesicular transport, possibly between the endoplasmic reticulum (ER)

${ }^{1}$ Corresponding author. and the Golgi apparatus (Segev et al. 1988; Bacon et al. 1989).

Mammalian homologs of ypt 1 and $\sec 4$ include the $r a b$ and smg25 family of proteins. Many of these Rab/ Smg25 proteins probably function analogously to ypt1 and sec4, in that they are involved in protein sorting and vesicular trafficking from the ER through the Golgi and on to the plasma membrane (Segev et al. 1988; Haubruck et al. 1989). One of the Rab proteins, namely rab3 /which is the same as Smg p25A) is found predominantly in the brain and the adrenal medulla (Burstein and Macara 1989; Darchen et al. 1990; Mizoguchi et al. 1990). A recent report has shown that Rab3A, a synaptic vesicleassociated protein (Fischer von Mollard et al. 1990), dissociates from the vesicle during the process of neurotransmitter secretion (Fischer von Mollard et al. 1991). This suggests that LMW G proteins may serve an important regulatory function in the control of neurotransmitter secretion.

The HT4 neural cell line was derived from mouse neuronal tissue and immortalized with a temperature-sensitive SV40 large T antigen (Mckay et al. 1988). This neural cell line secretes excitatory amino acids in response to membrane depolarization (Morimoto and Koshland 1990a), and both short- and long-term potentiation of neurotransmitter secretion can be expressed (Morimoto and Koshland 1990b). Potentiation of neurotransmitter secretion is mediated by the elevation of cAMP (Morimoto and Koshland 1990b, 1991b).

In the process of understanding the molecular 
mechansims responsible for potentiation of neurotransmitter secretion, we discovered a new gene whose sequence indicates that it is in the general small G-protein family but does not fit into any of the known families.

\section{Results and discussion}

In recent studies of the HT4 neural cell line, a search for a new $\mathrm{G}$ protein involved in neurotransmitter secretion was initiated. Two regions of conserved amino acid sequence (GNSSVGK and LVGNKCD) between $r a b$ (Touchot et al. 1987) and smg25 (Matsui et al. 1988) were used to design the oligonucleotide probes, as described in Materials and methods. Approximately 500,000 recombinant phage plaques from an HT4 cDNA library (cDL39) were screened using a mixture of oligonucleotides to these two peptide sequences. After several rounds of plaque purification, a single colony gave rise to a clone with a $1-k b$ insert. A partial restriction map and the sequencing strategy are shown in Figure 1.

The nucleotide sequence was determined using primers to the flanking vector sequences. To faciliate the complete sequencing of this clone, a 467-bp EcoRI fragment was subcloned, thus generating two vectors with approximately equal size inserts. Subsequently, oligonucleotide primers internal to the cloned fragment were used to verify the nucleotide sequence of the intact clone. Both the nucleotide and predicted amino acid sequence of this clone are presented in Figure 2. The open reading frame consisted of 624 nucleotides and encodes a protein of 208 amino acids, with a putative molecular mass of $23.3 \mathrm{kD}$.

The amino acid sequence of this gene identifies it as a member of the ras superfamily. Three amino acids that have been shown to be critical for GTP binding in the ras protein are conserved in this new $G$ protein at Lys-14, Phe-26, and Thr-33. In Figure 3, amino acid identity in the putative GTP-binding domains, at amino acid postitions 3-17, 30-38, 52-63, and 111-119 (Bourne et al. 1991 ), is $50-100 \%$ when compared with rab1 (Touchot et al. 1987), sec4 (Salminen and Novick 1987), or ypt1 (Gallwitz et al. 1983). Although the open reading frame lacks an initiator methionine, some interesting sequence comparisons to other known members of the ras super-

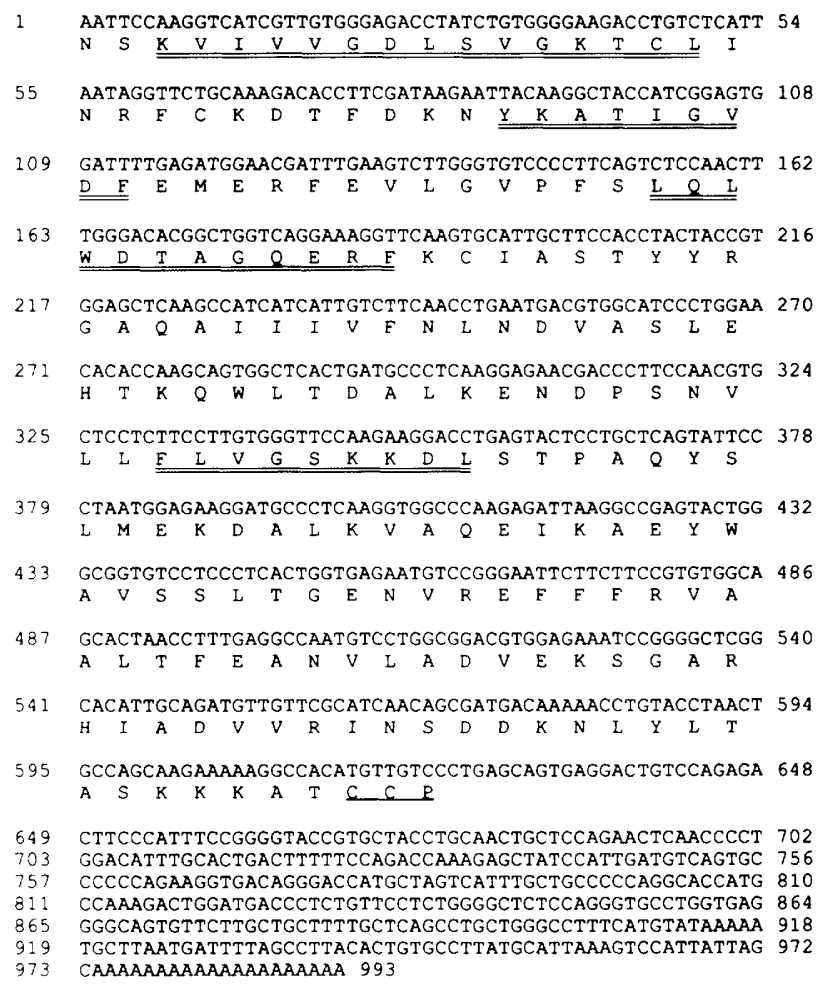

Figure 2. Nucleotide and predicted amino acid sequence. Numbers indicate the positions of nucleotides starting at the first nucleotide in the open reading frame. Double underlines indicate the consensus GTP-binding and GTPase sequence domains. The carboxyl terminus is underlined.

family indicate both similarities and differences, which make this clone a novel, new entity.

This new $\mathrm{G}$ protein is most closely related to $\mathrm{rab}$, sec4, and ypt1, with $32-34 \%$ amino acid identity. The next closest relatives would be ral (Polakis et al. 1989), rap (Pizon et al. 1988), rho (Chardin et al. 1988), rac (Didsbury et al. 1989), and ras (Capon et al. 1983), with 23$27 \%$ identity. For comparison, amino acid identity between ras and the other classes of LMW G proteins ranges from $21 \%$ identity for rho to $47 \%$ for ral. Within a particular class of $\mathrm{G}$ protein, amino acid identity can

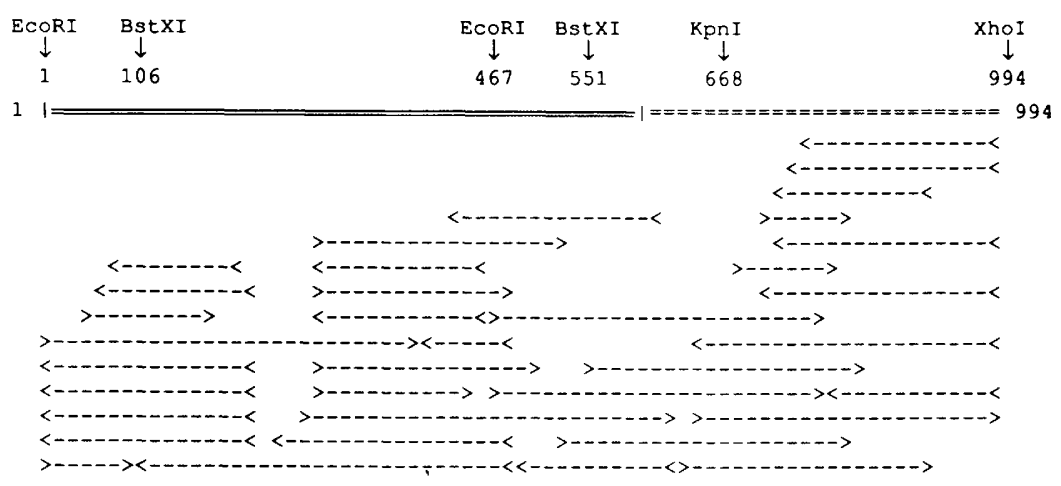

Figure 1. Restriction map and sequencing strategy. The cDNA insert is an EcoRI-Xhol restriction fragment and is aligned $5^{\prime} \rightarrow 3^{\prime}$. Restriction sites are indicated above the map; the numbers denote the positions of digestion. The open reading frame is indicated by the solid double lines and extends from bp 1 to 624 . The arrows indicate the direction and region of DNA sequencing. 
Figure 3. Comparison of amino acid sequences in the conserved GTP-binding domains. Identical amino acids to rah1 are highlighted in boxes. The sequences are ordered with respect to the weighted identical amino matches in the GTP-binding domains compared with rah1. The numbers to the left of each domain indicate the beginnning amino acid position for that sequence. Consensus sequence is based on amino acid homology; $(X)$ Any amino acid; (O) a hydrophobic amino acid (V, L, I, M, $\mathrm{C})$; $(\mathrm{Z})$ an aromatic amino acid $(\mathrm{F}, \mathrm{Y}, \mathrm{W})$; (B) serine (S) or threonine (T).

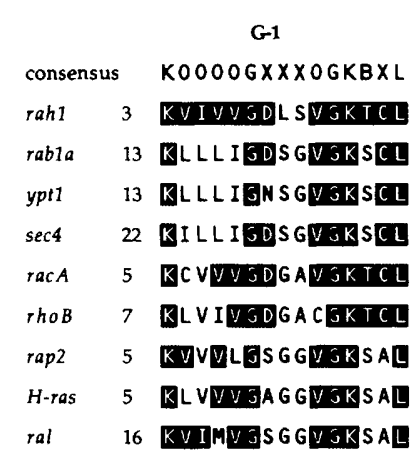

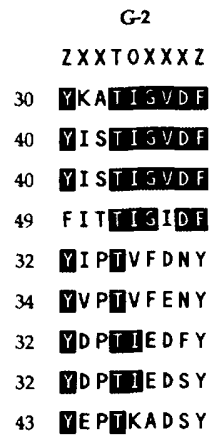

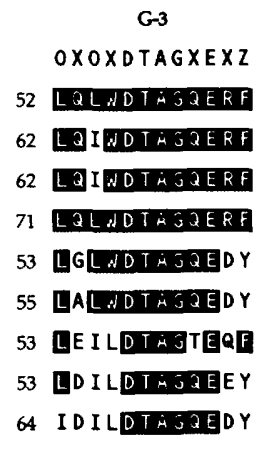

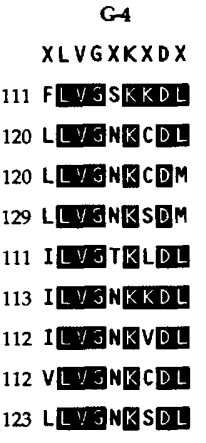

vary from $39 \%$ to $89 \%$. For example, the homology of rab1a to rab1b is $89 \%$; to $r a b 2,44 \%$; to rab3, $45 \%$; and to $r a b 4,39 \%$. To evaluate the significance of these amino acid identities, the amino acid sequence for each of these LMW G proteins was placed in random order and subjected to the same homology criteria. This analysis maintains the amino acid composition and provides an estimate of random chance for amino acid identity. By randomizing the order of amino acids, homology between members of the LMW G proteins gave an apparent amino acid identity score of $9 \pm 1 \%$ (mean \pm S.E., for $n=9$. Thus, the amino acid sequence of the HT4 G protein is sufficiently different from the other known members of the ras superfamily to qualify this gene as a member of a new class of LMW GTP-binding protein, designated rah for ras-related homolog.

A unique structural feature of rah1 is the carboxy-terminal amino acids (Table 1). The ras superfamily of $G$ proteins is known to be post-translationally modified by isoprenoid groups at a cysteine residue (see Maltese 1990; Gibbs 1991). The carboxyl terminus of these LMW $G$ proteins can be classified into four subgroups according to their amino acid sequences. The first group includes Ras p21, Rho, and G25K, with a termini of-CysA-A- $X$, where $\mathrm{A}$ is an aliphatic amino acid and $X$ is any amino acid. The cysteine residue is either farnesylated (Hancock et al. 1989) or geranylgeranylated (Yamane et al. 1991), and the -A-A- $X$ amino acids are then removed. The free carboxyl group on the carboxy-terminal cysteine is then methyl-esterified (Clarke et al. 1988; Stephenson and Clarke 1990).

The second and third groups of carboxyl termini have either the -Cys-Cys or -Cys- $X$-Cys motif, and the cysteines are modified with geranylgeranyl isoprenoid groups (Farnsworth et al. 1991; Khosravi-Far et al. 1991; Kinsella and Maltese 1991). The fourth group includes arf (Sewell and Kahn 1988) and contains no carboxy-terminal cysteine. The carboxyl terminus of $r a h 1$ is -CysCys-Pro. This carboxyl terminus is related most closely to the Rab family of -Cys-Cys and -Cys- $X$-Cys, but the carboxy-terminal proline is a novel structure for a LMW G protein.

To confirm the expression of this new G-protein clone, first-strand cDNA was generated from poly $(\mathrm{A})$ mRNA isolated from either undifferentiated or differentiated HT4 cells. Two sets of primers were used to perform polymerase chain reaction (PCR) amplification of this G-protein transcript. Primer set 1 consisted of oligonucleotides to an amino-terminal amino acid sequence (KVIVVGD) and to a region within the third conserved GTP-binding domain (TAGQERF). In Figure 4 (lane 2), a 183-bp PCR product was generated using the LMW G-protein plasmid as template for amplification. Firststrand cDNA from undifferentiated (lane 3 ) and differentiated (lane 4) HT4 cells also gave rise to a single 183-bp product. By making use of the oligonucleotide to the amino-terminal sequence KVIVVGD and to one in the carboxy-terminal region (FEANVLAD), a second set of primers defined a 511-bp fragment to the plasmid template (lane 5). Through the use of this second set of primers, amplification of the cDNA from undifferentiated (lane 6) and differentiated (lane 7) HT4 cells also produced a PCR product of $511 \mathrm{bp}$. Thus, this new LMW G protein is expressed in both the undifferentiated and differentiated state, consistent with the ability of this neural cell line to secrete excitatory amino acids.

Although the cellular function of rah1 is unknown, homology to $r a b, \sec 4$, and ypt1 classes of LMW G pro-

Table 1. Carboxyl termini of various LMW GTP-binding proteins

\begin{tabular}{|c|c|c|c|c|c|c|c|c|c|}
\hline \multicolumn{2}{|c|}{ new -C-C-P terminus } & \multicolumn{2}{|c|}{-C-A-A-X termini } & \multicolumn{2}{|c|}{-C-C termini } & \multicolumn{2}{|c|}{$-\mathrm{C} \cdot \mathrm{X} \cdot \mathrm{C}$ termini } & \multicolumn{2}{|c|}{ No Cys terminus } \\
\hline rah1 & $-\mathrm{T}-\mathrm{C}-\mathrm{C}-\mathrm{P}$ & $\begin{array}{l}\text { Ha-ras } \\
\text { ralA } \\
\text { rhoA } \\
\text { rac1 }\end{array}$ & $\begin{array}{l}-C-V-L-S \\
-C-C-I-L \\
-C-L-V-L \\
-C-L-L-L\end{array}$ & $\begin{array}{l}\text { ypt1 } \\
\text { sec4 } \\
\text { rab1a } \\
\text { rab1b } \\
\text { rab2 }\end{array}$ & $\begin{array}{l}-G \cdot G-C-C \\
-S-N-C-C \\
-G-G \cdot C \cdot C \\
-G-G-C-C \\
-G-G-C-C\end{array}$ & $\begin{array}{l}r a b 3 \\
r a b 4\end{array}$ & $\begin{array}{l}-D-C-A-C \\
-E-C-G-C\end{array}$ & arf & -R-N-Q-K \\
\hline
\end{tabular}




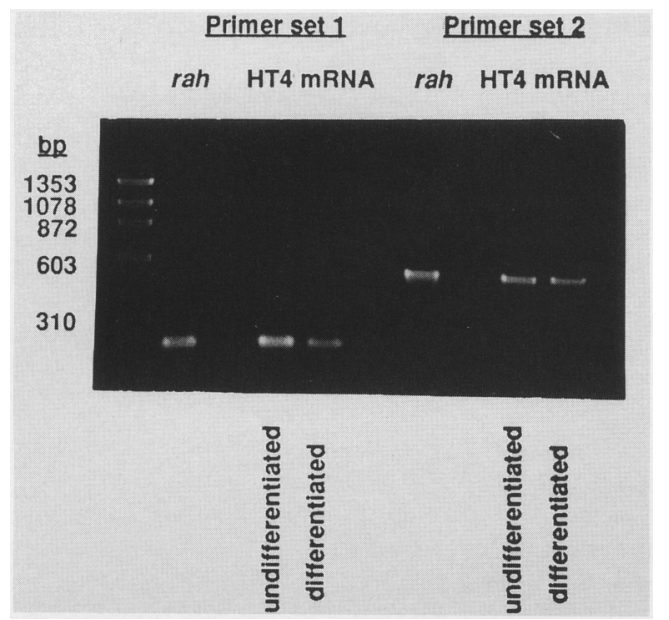

Figure 4. RNA analysis using PCR. Poly(A) mRNA was isolated from undifferentiated and differentiated HT4 cells. First strand cDNA was generated and used as a template for PCR amplification. Two sets of primers were used: Primer set 1 defines a 183-bp fragment; primer set 2 defines a 511 -bp fragment. (Lane 1) $500 \mathrm{ng}$ of a HaeIII digest of Phi-X 174 DNA; the size fragments are denoted in the left margin. (Lane 2) rah plasmid as template and oligonucleotides to primer set 1. (Lane 3) Undifferentiated HT4 mRNA as template and oligonucleotides to primer set 1. (Lane 4) Differentiated HT4 mRNA as template and oligonucleotides to primer set 1 . (Lane 5) rah plasmid as template and oligonucleotides to primer set 2. (Lane 6) Undifferentiated HT4 mRNA as template and oligonucleotides to primer set 2. (Lane 7) Differentiated HT4 mRNA as template and oligonucleotides to primer set 2 .

teins suggests a possible role in vesicular secretion, most likely functioning in the fusion of secretory vesicles with the plasma membrane. HT4 cells have been shown to express both short- and long-term potentiation of neurotransmitter secretion (Morimoto and Koshland 1990b, 1991a), and rah1 or possibly some other LMW G protein may function as an important signal transduction component in the expression of potentiation.

\section{Materials and methods}

Cell growth

HT4 cells were maintained in Dulbecco's modified Eagle medium supplemented with $10 \%$ fetal bovine serum at $33^{\circ} \mathrm{C}$. Cells were differentiated by growth at the nonpermissive temperature for the SV40 large T antigen for 5-7 days. HT4 cells were obtained from Ronald McKay at MIT (Cambridge, MA).

\section{Construction of cDNA libraries}

cDNA libraries were constructed from poly $(A)$ mRNA isolated from either differentiated or nondifferentiated HT4 cells. mRNA was isolated in a single-step extraction with guanidinium thiocyanate/phenol/chloroform /Chomczynski and Sacchi 1987). Poly(A) RNA was purified on oligo(dT) cellulose, and 10 $\mu \mathrm{g}$ was used for first-strand cDNA synthesis. Template mRNA was primed with a poly(dT) oligonucleotide containing an internal Xhol restriction site. cDNA was synthesized using Moloney murine leukemia virus reverse transcriptase and a nucle- otide mixture containing 5-methyl dCTP. During second-strand synthesis, RNase $\mathrm{H}$ and DNA polymerase I were used to replace the RNA strand with deoxynucleotides. T4 DNA polymerase was then used to blunt the ends of the cDNA, and EcoRI adaptors were ligated to the blunt termini. The cDNA was digested with XhoI to expose the XhoI site at the $3^{\prime}$ end of the cDNA. The incorporation of 5-methyl dCTP during the first-strand synthesis prevented the internal restriction of the cDNA inserts. The cDNA was directionally cloned into Lambda Zap II (Stratagene). Size fractionation of the cDNA gave inserts of sizes ranging from 0.5 to $3.5 \mathrm{~kb}$. Phage DNA was packaged using Gigapack II Gold packaging extracts (Stratagene), which gave rise to $\sim 10^{6}$ recombinant clones. The library was amplified once in the PLK-F' Escherichia coli strain. The cDNA library constructed from undifferentiated HT4 cells was designated cDL33, and the library constructed from differentiated HT4 cells was designated cDL39.

\section{Isolation of $\mathrm{CDNA}$ clones}

A mixture of two oligonucleotides with the sequence 5 - CTTGCCCACGCTGCTGTTTCC-3' and 5'-GTCACACTTGTTCCCTACCAG-3' was end-labeled with T4 polynucleotide kinase and $\left[\gamma^{-32} \mathrm{P}\right] \mathrm{ATP}$ (Amersham, $6000 \mathrm{Ci} / \mathrm{mmole}$ ). These oligonucleotides were used to screen the cDL39 cDNA library. Hybridization was conducted under low stringency in $6 \times$ SSC, $5 \times$ Denhardt's solution, and $0.05 \% \mathrm{NaPP}_{\mathrm{i}}$ at room temperature for $24 \mathrm{hr}$. Filters were washed initially in $6 \times \mathrm{SSC}$ containing $0.05 \% \mathrm{NaPP}_{\mathrm{i}}$ and $0.1 \% \mathrm{SDS}$, and the wash stringency was increased to $2 \times$ SSC containing $0.05 \% \mathrm{NaPP}_{\mathrm{i}}$ and $0.1 \% \mathrm{SDS}$. Ten independent clones were isolated, and pBluescript phagemids were excised in vivo by coinfection with R408 helper phage (Stratagene).

\section{DNA sequence analysis}

The nucleotide sequence was initially determined using a modification of the Sanger dideoxy method (Sequenase, U.S. Biochemicall. Sequence data were verified using the linear amplication DNA sequencing method (dsCycle Sequencing, GIBCO/ $\mathrm{BRL}$ ). Briefly, 1 pmole of the appropriate sequencing primer was end labeled with T4 polynucleotide kinase and $\left[\gamma^{32} \mathrm{P}\right]$ ATP. The end-labeled primer was combined with $290 \mathrm{ng}$ of plasmid DNA in Taq sequencing buffer $(30 \mathrm{~mm}$ Tris- $\mathrm{HCl}$ at $\mathrm{pH} 7.8,5 \mathrm{~mm}$ $\mathrm{MgCl}_{2}, 30 \mathrm{mM} \mathrm{KCl}$, and $0.5 \% \mathrm{~W}-1$ ) containing 2.5 units of $\mathrm{Taq}$ polymerase. Four separate termination reactions were thermal cycled 30 times at $95^{\circ} \mathrm{C}$ for $30 \mathrm{sec}, 50^{\circ} \mathrm{C}$ for $30 \mathrm{sec}$, and $72^{\circ} \mathrm{C}$ for $1 \mathrm{~min}$, with a final elongation step of $72^{\circ} \mathrm{C}$ for $5 \mathrm{~min}$. The termination mixes contained as the final concentration $10 \mu \mathrm{M}$ each of dATP, dCTP, dTTP, and $\mathrm{c}^{7}$-deaza-dGTP. The dideoxy nucleotide concentrations in the respective termination reactions were $0.4 \mathrm{mM}$ ddATP, $0.2 \mathrm{~mm}$ ddCTP, $0.04 \mathrm{~mm}$ ddGTP, and 0.4 mM ddTTP. The reactions were stopped with one-third volume of $95 \%$ foramide, $10 \mathrm{~mm}$ EDTA, $0.1 \%$ bromphenol blue, and $0.1 \%$ xylene cyanol. This linear amplification method allowed sequencing of relatively impure double-stranded template DNA. Nucleotide chain elongation and termination at temperatures $>70^{\circ} \mathrm{C}$ prevented the formation of secondary structures, which often resulted in premature chain termination.

Sequence comparisions were performed by using the Intelligenetics Suite on a Sun 3/50 computer.

\section{RNA analysis}

Poly $|A|$ mRNA was isolated from both differentiated and undifferentiated HT4 cells. First-strand cDNA was synthesized by 
AMV reverse transcriptase in the presence of methyl-mercury hydroxide (cDNA cycle, Invitrogen). The rah G-protein transcripts were amplified using the GeneAmp PCR (Perkin-Elmer Cetus). Two primer combinations were used to generate 183and 511-bp fragments. Primer set 1 consisted of the oligonucleotides 5'-AAGGTCATCGTTGTGGGAGAC-3' and 5'AACCTTTCCTGACCAGCCGTG-3'. Primer set 2 consisted of 5'-AAGGTCATCGTTGTGGGAGAC-3' and 5' - CCGCCAGGACATTGGCCTCAAAG-3'. The amplification reactions were cycled 30 times with the following temperature profile: $95^{\circ} \mathrm{C}, 30 \mathrm{sec} ; 50^{\circ} \mathrm{C}, 30 \mathrm{sec}^{\prime} 72^{\circ} \mathrm{C}, 1 \mathrm{~min}$. Nucleic acid fragments were separated on a $1.7 \%$ agarose gel and stained with ethidium bromide.

\section{Acknowledgments}

We thank Dr. Steve Clarke for his helpful discussions. This work was supported by grant DK09765 from the National Institutes of Health and by a grant from the W.M. Keck foundation.

The publication costs of this article were defrayed in part by payment of page charges. This article must therefore be hereby marked "advertisement" in accordance with 18 USC section 1734 solely to indicate this fact.

\section{References}

Bacon, R.A., A. Salminen, H. Ruohola, P. Novick, and S. FerroNovick. 1989. The GTP-binding protein Yptl is required for transport in vitro: The Golgi apparatus is defective in ypt 1 mutants. I. Cell Biol. 109: 1015-1022.

Bourne, H.R. 1988. Do GTPases direct membrane traffic in secretion? Cell 53: 669-671.

Bourne, H.R., D.A. Sanders, and F. McCormick. 1990. The GTPase superfamily: A conserved switch for diverse cell functions. Nature 348: 125-132.

- 1991. The GTPase superfamily: Conserved structure and molecular mechanism. Nature 349: 117-127.

Burstein, E. and I.G. Macara. 1989. The ras-like protein p $25^{\text {rab3A }}$ is partially cytosolic and is expressed only in neural tissue. Mol. Cell. Biol. 9: 4807-4811.

Capon, D.J., E.Y. Chen, A.D. Levinson, P.H. Seeburg, and D.V. Goeddel. 1983. Complete nucleotide sequences of the T24 human bladder carcinoma oncogene and its normal homologue. Nature 302: 33-37.

Chardin, P., P. Madaule, and A. Tavitian. 1988. Coding sequence of human rho cDNAs clone 6 and clone 9. Nucleic Acids Res. 16: 2717.

Chomczynski, P. and N. Sacchi. 1987. Single-step method of RNA isolation by acid guanidinium thiocyanate-phenolchloroform extraction. Anal. Biochem. 162: 156-159.

Clarke, S., J.P. Vogel, R.J. Deschenes, and J. Stock. 1988. Posttranslational modification of the Ha-ras oncogene protein: Evidence for a third class of protein carboxyl methyltransferases. Proc. Natl. Acad. Sci 85: 4643-4647.

Darchen, F., A. Zahraoui, F. Hammel, M.-P. Monteils, A. Tavitian, and D. Scherman. 1990. Association of the GTP-binding protein Rab3A with bovine adrenal chromaffin granules. Proc. Natl. Acad. Sci. 87: 5692-5696.

Didsbury, J., R.F. Weber, G.M. Bokoch, T. Evans, and R. Snyderman. 1989. rac, a novel ras-related family of proteins that are Botulinum toxin substrates. I. Biol. Chem. 264: 1637816382.

Farnsworth, C.C., M. Kawata, Y. Yoshida, Y. Takai, M.H. Gelb, and J.A. Glomset. 1991. C terminus of the small GTP-binding protein smg p25A contains two geranylgeranylated cys- teine residues and a methyl ester. Proc. Natl. Acad. Sci. 88: 6196-6200.

Fischer von Mollard, G., G.A. Mignery, M. Baumert, M.S. Perin, T.J. Hanson, P.M. Burger, R. Jahn, and T.C. Sudhof. 1990. rab3 is a small GTP-binding protein exclusively localized to synaptic vesicles. Proc. Natl. Acad. Sci. 87: 1988-1992.

Fischer von Mollard, G., T.C. Sudhof, and R. Jahn. 1991. A small GTP-binding protein dissociates from synaptic vesicles dur ing exocytosis. Nature 349: 79-81.

Gallwitz, D., C. Donath, and C. Sander. 1983. A yeast gene encoding a protein homologous to the human c-has/bas proto-oncogene product. Nature 306: 704-707.

Gibbs, J.B. 1991. Ras C-terminal processing enzymes-new drug targets? Cell 65: $1-4$.

Hall, A. 1990. The cellular functions of small GTP-binding proteins. Science 249: 635-640.

Haubruck, H., R. Prange, C. Vorgias, and D. Gallwitz. 1989. The ras-related mouse ypt l protein can functionally replace the YPT1 gene product in yeast. EMBO /. 8: 1427-1432.

Hancock, J.T., A.I. Magee, J.E. Childs, and C.J. Marshall. 1989. All ras proteins are polyisoprenylated but only some are palmitoylated. Cell 57: 1167-1177.

Khosravi-Far, R., R.J. Lutz, A.D. Cox, L. Conroy, J.R. Bourne, M. Sinensky, W.E. Balch, J.E. Buss, and C.J. Der. 1991. Isopren oid modification of rab proteins terminating in $\mathrm{CC}$ or $\mathrm{CXC}$ motifs. Proc. Natl. Acad. Sci. 88: 6264-6268.

Kinsella, B.T. and W.A. Maltese. 1991. rab GTP-binding proteins implicated in vesicular transport are isoprenylated in vitro at cysteines within a novel carboxyl-terminal motif. $J$. Biol. Chem. 266: 8540-8544.

Maltese, W.A. 1990. Posttranslational modification of proteins by isoprenoids in mammalian cells. FASEB I. 4: 3319-3328.

Matsui, Y., A. Kikuchi, J. Kondo, T. Hishida, Y. Teranishi, and Y. Takai. 1988. Nucleotide and deduced amino acid sequences of a GTP-binding protein family with molecular weights of 25,000 from bovine brain. I. Biol. Chem. 263: 11071-11074.

McKay, R., K. Frederiksen, P.-J. Jat, and D. Levy. 1988. Reconstructing the brain from immortal cell lines. Prog. Brain Res. 78: 647-649.

Mizoguchi, A., S. Kim, T. Ueda, A. Kikuchi, H. Yorifuji, N Hirokawa, and Y. Takai. 1990. Localization and subcellular distribution of $s m g$ p25A, a ras p21-like GTP-binding protein, in rat brain. J. Biol. Chem. 265: 11872-11879.

Morimoto, B.H. and D.E. Koshland Jr. 1990a. Excitatory amino acid uptake and N-methyl-D-aspartate-mediated secretion in a neural cell line. Proc. Natl. Acad. Sci. 88: 3518-3521.

- 1990b. Induction and expression of long- and short-term potentiation in a neural cell line. Neuron 5: 875-880.

- 1991a. Short-term and long-term memory in single cells. FASEB I. 5: 2061-2067.

- 1991b. Identification of cAMP as the response regulator for neurosecretory potentiation. Proc. Natl. Acad. Sci. (in press).

Pizon, V., P. Chardin, I. Lerosey, B. Olofsson, and A. Tavitian. 1988. Human cDNAs rap1 and rap2 homologous to the Drosophila gene Dras3 encode proteins closely related to ras in the "effector" region. Oncogene 3: 201-204.

Polakis, P.G., R.F. Weber, B. Nevins, J.R. Didsbury, T. Evans, and R. Snyderman. 1989. Identification of the ral and rac1 gene products, low molecular mass GTP-binding proteins from human platelets. I. Biol. Chem. 264: 16383-16389.

Salminen, A. and P.J. Novick. 1987. A ras-like protein is required for a post-Golgi event in yeast secretion. Cell 49: $527-538$.

Segev, N., J. Mulholland, and D. Botstein. 1988. The yeast GTP. 
binding YPT1 protein and a mammalian counterpart are associated with the secretion machinery. Cell 52: 915-924.

Sewell, J.L. and R.A. Kahn. 1988. Sequences of the bovine and yeast ADP-ribosylation factor and comparision to other GTP-binding proteins. Proc. Natl. Acad. Sci. 85: 4620-4624.

Stephenson, R.C. and S. Clarke. 1990. Identification of a C-terminal protein carboxyl methyltransferase in rat liver membranes utilizing a synthetic farnesyl cysteine-containing peptide substrate. I. Biol. Chem. 265: 16248-16254.

Touchot, N., P. Chardin, and A. Tavitian. 1987. Four additional members of the ras gene superfamily isolated by an oligonucleotide strategy: Molecular cloning of YPT-related cDNAs from a rat brain library. Proc. Natl. Acad. Sci. 84: 82108214.

Walworth, N.C., B. Goud, A. K. Kabcenell, and P.J. Novick. 1989. Mutational analysis of SEC4 suggests a cyclical mechanism for the regulation of vesicular traffic. $E M B O \quad J$ 8: 1685-1693.

Yamane, H.K., C.C. Farnsworth, H. Xie, T. Evans, W.N. Howald, M.H. Gelb, J.A. Glomset, S. Clarke, and B.K.-K. Fung. 1991. Membrane-binding domain of the small $G$ protein G25K contains an S-(all-trans-geranylgeranyl)cysteine methyl ester at its carboxyl terminus. Proc. Natl. Acad. Sci. 88: $286-290$. 


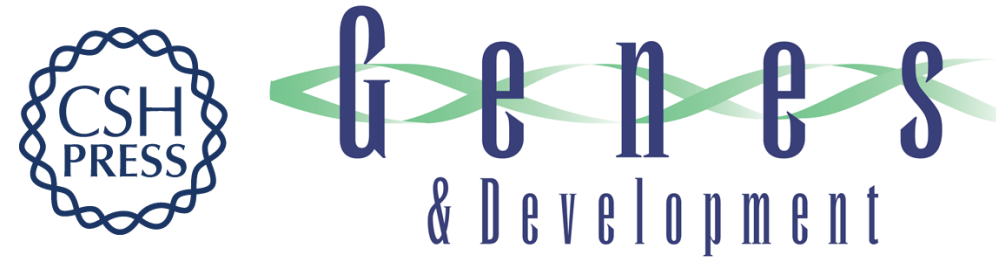

\section{Molecular cloning of a member of a new class of low-molecular-weight GTP-binding proteins.}

B H Morimoto, C C Chuang and D E Koshland

Genes Dev. 1991, 5:

Access the most recent version at doi:10.1101/gad.5.12b.2386

References This article cites 37 articles, 17 of which can be accessed free at:

http://genesdev.cshlp.org/content/5/12b/2386.full.html\#ref-list-1

License

Email Alerting

Service

Receive free email alerts when new articles cite this article - sign up in the box at the top right corner of the article or click here.

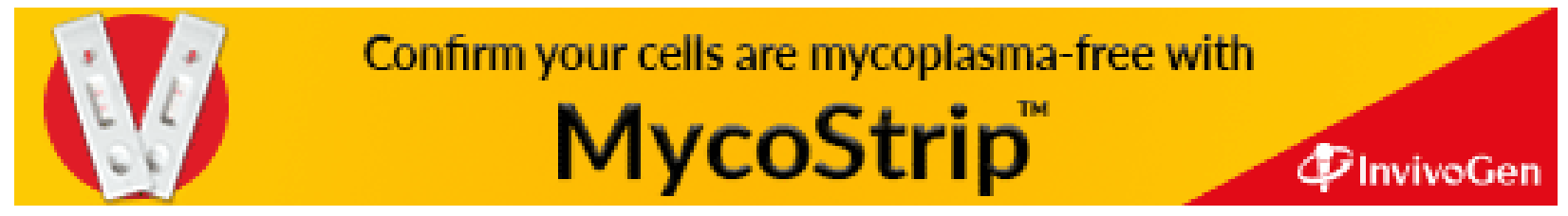

